\title{
PENGARUH PEMBERIAN JUS BELIMBING (Averrhoa Carambola) DAN BUAH NAGA (Hylocereus Undatus) TERHADAP TEKANAN DARAH PADA PASIEN HIPERTENSI DI RUANG INTERNE RSUD PADANG PANJANG TAHUN 2017
}

\author{
Mira Malfita ${ }^{1}$, Nurhamidah ${ }^{2}$

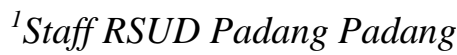 \\ ${ }^{2}$ Sekolah Tinggi Ilmu Kesehatan Perintis Padang \\ Jalan Adinegoro KM 17 Simpang Kalumpang Padang \\ Email: nurhamidah_29@yahoo.com
}

\begin{abstract}
Hypertension is a condition in which a person experiences an increase in blood pressure above normal resulting in increased morbidity and mortality / mortality. Star fruit and dragon fruit can also be used to overcome hypertension. Fruit starfruit and dragon fruit has a lot of antioxidant substances such as vitamin $\mathrm{C}$, Flavonoid and niacin and magnesium that can flex or relax the arterial blood vessels. In addition, star fruit and dragon fruit also have diuretic calcium contents atua peluruh urine so increase the intake of minerals that play a role in lowering high blood pressure. The purpose of this research is to know the effect of juice of star fruit (Averrhoa Carambola) and dragon fruit (hylocereus undatus) to blood pressure in hypertension patient in Internal Room of RSUD Padang Panjang Year 2017.The study was conducted for 6 days with 1 day feeding. The research design used Quasi-Ekperiment using One group pre-post test design on 15 respondents with hypertension. The statistical test obtained $\mathrm{p}$ value of systolic blood pressure $=$ 0.000 and $p$ value of diastolic blood pressure $=0.001$ then ha accepted, meaning there is influence of star fruit juice and dragon fruit to blood pressure patient room internal hospital RSUD Padang Panjang.Based on the results of this study, researchers suggested that starfruit and dragon juice can be used as an independent intervention, especially for people with hypertension.
\end{abstract}

Key words: Star fruit juice and dragon fruit, decreased blood pressure

\section{PENDAHULUAN}

Hipertensi adalah suatu keadaan dimana seseorang mengalami peningkatan tekanan darah di atas normal yang mengakibatkan peningkatan angka kesakitan (morbiditas) dan angka kematian/mortalitas. Tekanan darah $140 / 90 \mathrm{mmHg}$ didasarkan pada dua fase dalam setiap denyut jantung yaitu fase sistolik 140 menunjukkan fase darah yang sedang dipompa oleh jantung dan fase diastolik 90 menunjukkan fase darah yang kembali ke jantung (Endang, 2014).

Organisasi Kesehatan Dunia (WHO) mencatat pada tahun 2012 sedikit sejumlah 839 juta kasus hipertensi, diperkirakan menjadi 1,15 milyar pada tahun 2025 atau sekitar 29\% dari total penduduk dunia, dimana penderitanya lebih banyak pada wanita (30\%) dibandingkan pria $(29 \%)$. Sekitar $80 \%$ kenaikan kasus hipertensi terjadi terutama di negara-negara berkembang (Endang, 2014).

Menurut hasil Riskesdas tahun 2013 dengan menggunakan unit analisis individu menunjukkan bahwa secara nasional $25,8 \%$ penduduk Indonesia menderita penyakit hipertensi. Jika saat ini penduduk Indonesia sebesar 252.124.458 jiwa maka terdapat 65.048.110 jiwa yang menderita hipertensi. 
Suatu kondisi yang cukup mengejutkan. Terdapat 13 provinsi yang persentasenya melebihi angka nasional, dengan tertinggi di Provinsi Bangka Belitung (30,9\%), untuk Sumatera Barat sendiri terdapat 22,6\% penduduk yang menderita hipertensi (Kemenkes RI, 2014).

Sedangkan di RSUD Padang Panjang sendiri, diketahui hipertensi merupakan nomor 1 (satu) dalam 10 (sepuluh penyakit terbanyak) dimana pada tahun 2015 tercatat sebanyak 577 kasus hipertensi.Sedangkan pada tahun 2016 trimester I didapatkan sebanyak 154 kasus, pada trimester II 105 kasus dan pada trimester 3 sudah tercatat sebanyak 138 kasus (RSUD Padang Pnjang, 2015, 2016).

Buah belimbing dan buah naga memiliki banyak kandungan zat antioksidan seperti vitamin C, Flavonoid serta niasin dan magnesium yang dapat melenturkan atau merelaksasi pembuluh darah arteri, selain itu, buah belimbing dan buah naga juga memiliki kandungan kalsium yang bersifat diuretik atua peluruh air seni sehingga meningkatkan asupan mineral yang berperan pada penurunan tekanan darah tinggi.

Tujuan dari penelitian ini untuk mengetahui pengaruh pemberian jus belimbing (Averrhoa Carambola) dan buah naga (hylocereus undatus) terhadap tekanan darah pada pasien hipertensi di Ruang Interne RSUD Padang Panjang Tahun 2017.

\section{METODE PENELITIAN}

Tabel 4.1 Pengaruh pemberian jus belimbing dan buah naga terhadap tekanan darah sistolik pada pasien hipertensi di Ruang Interne RSUD Padang Panjang

\begin{tabular}{lccccc}
\hline \multicolumn{1}{c}{ Tekanan Darah Sistolik } & Mean & $\mathrm{N}$ & SD & $\mathrm{t}$ & P value \\
\hline Sebelum & 161,93 & 15 & 18,065 & \multirow{2}{*}{6,607} & \multirow{2}{*}{0,000} \\
Sesudah & 132,00 & 15 & 13,768 & & \\
\hline
\end{tabular}

Berdasarkan tabel diatas dapat dilihat bahwa rata-rata (mean) tekanan darah sistolik sebelum perlakuan adalah sebesar 161,93 $\mathrm{mmHg}$ dan sesudah perlakuan adalah sebesar
Jenis penelitian ini menggunakan Quasy Eksperiment yang artinya eksperimen semu sedangkan desainnya One Group Pretest Postest, yaitu sebelum diberikan jus belimbing dan buah naga terlebih dahulu dilakukan pretest (pengukuran tekanan darah) kemudian setelah perlakuan (pemberian jus belimbing dan buah naga) maka dilakukan lagi postest (pengukuran tekanan sesudah perlakuan) untuk mengetahui adanya perubahan tekanan darah.

Tenik sampling yang digunakan dalam penelitian ini adalah purposive sampling yaitu teknik penepatan sampel berdasarkan pertimbangan tertentu yang dibuat oleh peneliti sendiri berdasarkan ciri ciri atau sifat-sifat populasi yang sudah diketahui sebelumnya (Notoadmojo, 2010).

Menurut Roscoe (1975) dalam Sugiyono (2010) untuk penelitian eksperimen sederhana maka jumlah anggota sampel masing-masing kelompok antara 10-20 orang. Jadi jumlah sampel pada penelitian ini ditetapkan minimal sebanyak 15 orang.

\section{HASIL DAN PEMBAHASAN}

\section{Pengaruh Pemberian Jus Belimbing dan Buah Naga Terhadap Tekanan Darah Sistolik pada Pasien Hipertensi}

Pengaruh pemberian jus belimbing dan buah naga terhadap tekanan darah sistolik pada pasien hipertensi di Ruang Interne RSUD Padang Panjang dapat dilihat pada tabel dibawah ini

132,00 mmHg. Hasil uji statistik (paired t-test) menunjukkan nilai $\mathrm{p}$ value sebesar 0,000 $(p<0,05)$ berarti menunjukkan bahwa ada pengaruh pengaruh pemberian jus belimbing 
dan buah naga terhadap tekanan darah sistolik pada pasien hipertensi di Ruang Interne RSUD Padang Panjang.

\section{Pengaruh Pemberian Jus Belimbing dan Buah Naga Terhadap Tekanan Darah Diastolik pada Pasien Hipertensi}

Pengaruh pemberian jus belimbing dan buah naga terhadap tekanan darah diastolik pada pasien hipertensi di Ruang Interne RSUD Padang Panjang

Tabel 4.2 Pengaruh pemberian jus belimbing dan buah naga terhadap tekanan darah diastolik pada pasien hipertensi di Ruang Interne RSUD Padang Panjang

\begin{tabular}{lccccc}
\hline \multicolumn{1}{c}{ Tekanan Darah Diastolik } & Mean & N & t & P value \\
\hline Sebelum & 89,13 & 15 & \multirow{2}{*}{4,192} & 0,001 \\
Sesudah & 74,73 & 15 & & \\
\hline
\end{tabular}

Berdasarkan tabel diatas dapat dilihat bahwa rata-rata (mean) tekanan darah diastolik sebelum perlakuan adalah sebesar $89,13 \mathrm{mmHg}$ dan sesudah perlakuan adalah sebesar 74,73 mmHg. Hasil uji statistik (paired t-test) menunjukkan nilai $\mathrm{p}$ value sebesar 0,001 $(\mathrm{p}<0,05)$ berarti menunjukkan bahwa ada pengaruh pengaruh pemberian jus belimbing dan buah naga terhadap tekanan darah diastolik pada pasien hipertensi di Ruang Interne RSUD Padang Panjang.

Hasil penelitian ini sejalan dengan penelitian sebelumnya yang dilakukan oleh Steffi Grafika (2011), tentang pengaruh jus buah naga merah (Hylocereus polyrhizus) terhadap tekanan darah normal pada perempuan dewasa, menyimpulkan bahwa ada penurunan tekanan darah pasien hipertensi setelah diberikan jus buah naga.

Hasil penelitian Yuli Amran (2010), tentang pengaruh tambahan asupan kalium dari diet terhadap penurunan hipertensi sistolik tingkat sedang pada lanjut usia, dari hasil penelitian ini didapatkan bahwa asupan tambahan kalium berasal dari buah-buahan dalam diet telah berhasil menurunkan tekanan darah sistolik.

Penelitian Iip Ardiyanto (2014), tentang efektifitas jus belimbing terhadap penurunan tekanan darah pada lansia di Kelurahan Tawangmas Baru Kecamatan Semarang Barat, menemukan bahwa adanya pengaruh pemberian jus belimbing terhadap penurunan tekanan pada lansia dengan hipertensi.

Penelitian Febby Haedra (2013), tentang faktor-faktor yang berhubungan dengan tekanan darah di Puskesmas Telaga Murni, Cikarang Barat, menemukan bahwa asupan natrium, kalium berhubungan secara statistik dengan tekanan darah.

Penelitian Argi Virgona Bangun (2014), tentang pengaruh terapi jus belimbing manis (averhoa carambola linn) terhadap tekanan darah lansia dengan hipertensi di Puskesmas Citeureup Kota Cimahi, menemukan bahwa terdapat pengaruh tekanan darah sistolik dan diastolik sebelum dan sesudah mengkonsumsi jus belimbing manis terhadap tekanan darah pada lansia penderita hipertensi.

Berdasarkan hasil penelitian didapatkan bahwa rata-rata (mean) tekanan darah sistolik sebelum perlakuan adalah sebesar 161,93 $\mathrm{mmHg}$ dan sesudah perlakuan adalah sebesar $132 \mathrm{mmHg}$. Hasil uji statistik (paired t-test) menunjukkan nilai $\mathrm{p}$ value sebesar 0,000 $(p<0,05)$ berarti menunjukkan bahwa ada pengaruh pengaruh pemberian jus belimbing dan buah naga terhadap tekanan darah sistolik pada pasien hipertensi di Ruang Interne RSUD Padang Panjang.

Berdasarkan tabel 4.4 diatas dapat dilihat bahwa rata-rata (mean) tekanan darah diastolik sebelum perlakuan adalah sebesar $89,13 \mathrm{mmHg}$ dan sesudah perlakuan adalah sebesar 74,73 
mmHg. Hasil uji statistik (paired t-test) menunjukkan nilai $\mathrm{p}$ value sebesar 0,001 $(\mathrm{p}<0,05)$ berarti menunjukkan bahwa ada pengaruh pengaruhpemberian jus belimbing dan buah naga terhadap tekanan darah diastolik pada pasien hipertensi di Ruang Interne RSUD Padang Panjang.

Hasil penelitian ini sejalan dengan penelitian sebelumnya yang dilakukan oleh Steffi Grafika (2011) tentang pengaruh jus buah naga merah (Hylocereus polyrhizus) terhadap tekanan darah normal pada perempuan dewasa, menyimpulkan bahwa buah naga merah menurunkan tekanan darah normal pada perempuan dewasa.

Penelitian Iip Ardiyanto, dkk (2014) tentangefektifitas jus belimbing terhadap penurunan tekanan darah pada lansia di Kelurahan Tawangmas Baru Kecamatan Semarang Barat, Uji statistic yang digunakan adalah uji Wilcoxon. Dari hasil uji Wilcoxon didapatkan $\mathrm{p}$ value tekanan darah sistolik = 0.000 dan $\mathrm{p}$ value tekanan darah diastolik $=$ 0.000 maka Ha diterima, artinya ada pengaruh pemberian jus belimbing terhadap penurunan tekanan pada lansia dengan hipertensi.

Pada dasarnya buah belimbing mengandung kadar kalium yang tinggi serta natrium yang rendah sebagai obat anti hipertensi. Kandungan kalium (potassium) dalam 1 buah belimbing (127 gram) adalah sebesar $207 \mathrm{mg}$. Hal ini menunjukkan bahwa kalium dalam buah belimbing mempunyai jumlah yang paling banyak dari jumlah mineral yang ada dalam kandungan 1 buah belimbing (Afrianti, 2010).

Terjadinya penurunan tekanan darah responden disebabkan oleh karena kandungan buah belimbing yang kaya akan kalium dan rendah natrium. Dimana dalam hal ini awal mula terjadinya hipertensi adalah melalui terbentuknya Angiostensin I yang diubah menjadi Angiostensin II oleh ACE (Angiostensin I - Converting Enzyme) yang memiliki peran dalam menaikkan tekanan darah melalui 2 aksi utama, yaitu menurunnya cairan intraseluler dan meningkatnya cairan ekstraseluler dalam tubuh.Namun dengan pemberian terapi buah belimbing yang tinggi kalium dan rendah natrium kepada responden yang menderita hipertensi, maka 2 aksi utama tersebut telah mengalami perubahan arah dari semula. Kalium yang tinggi akan mampu menurunkan produksi atau sekresi hormon antidiuretik $(\mathrm{ADH})$ dan rasa haus. Hormon ini bekerja pada ginjal untuk mengatur osmolalitas dan volume urine, dengan menurunnya ADH, maka urine yang diekskresikan keluar tubuh akan meningkat, sehingga menjadi encer dengan osmolalitas yang rendah, untuk memekatkannya volume cairan intraseluler akan ditingkatkan dengan cara menarik cairan dari bagian ekstraseluler. Sedangkan menurunnya konsentrasi $\mathrm{NaCl}$ akan dipekatkan dengan cara menurunkan cairan ekstraseluler yang kemudian akan menurunkan tekanan darah (Astawan Made, 2010).

Dengan demikian, dapat dinyatakan bahwa fakta adanya penurunan nilai rata-rata MAP post test penderita hipertensi (responden) telah sesuai dengan teori yang menyatakan bahwa buah belimbing dan buah naga dapat dimanfaatkan untuk menurunkan tekanan darah tinggi.Sehingga terjadinya penurunan rata-rata sistolik dan distolik ini terjadi oleh karena responden telah diberikan terapi buah belimbing dan buah naga, dan keadaan ini menunjukkan bahwa pemberian terapi buah belimbing dan buah naga efektif untuk menurunkan tekanan darah responden yang menderita hipertensi.

\section{KESIMPULAN}

\section{Kesimpulan}

Berdasarkan hasil penelitian dan pembahasan diatas maka dapat disimpulkan sebagai berikut: Ada pengaruh pengaruh pemberian jus belimbing dan buah naga terhadap tekanan darah pada pasien hipertensi di Ruang Interne RSUD Padang Panjang ditandai dengan hasil uji statistik $\mathrm{p}$ value < 0.05 .

\section{Saran}

Hasil penelitian ini dapat dijadikan sebagai bahan acuan atau dasar untuk melakukan penelitian selanjutnya terutama mengenai efektifitas pemberian jus belimbing 
dan buah naga terhadap penurunan tekanan darah.Peneliti mengharapkan untuk peneliti selanjutnya dapat ditambahkan untuk jumlah responden, jumlah waktu yang lebih lama lagi dan juga jumlah takaran jus belimbimng dan buah naga yang lebih banyak.

\section{DAFTAR KEPUSTAKAAN}

Arikunto. 2010. Prosedur penelitian : Suatu Pendekatan Praktik. (Edisi.Revisi). Rineka Cipta :Jakarta.

Bangun AV. 2014. Pengaruh terapi jus belimbing manis (averhoa carambola linn) terhadap tekanan darah lansia dengan hipertensi di Puskesmas Citeureup Kota Cimahi. Jurnal Penelitian.

Bambang C. 2010. Cara Sukses Berkebun Belimbing Manis. Pustaka Mina.Jakarta

Damayanti. 2013. Sembuh Total Diabetes, Asam Urat, Hipertensi Tanpa Obat. Pinang Merah Publisher.Yogyakarta.

Dwipayanti PI. 2011. Efektifitas buah belimbing terhadap penurunan tekanan darah pada penderita hipertensi di Sumolepen Kelurahan Balongsari Kota Mojokerto. Jurnal Penelitian

Endang T. 2014. Pelayanan Keperawatan Bagi Penderita Hipertensi Secara Terpadu. Graha Ilmu. Yogyakarta

Hendry. 2012. Menentukan Ukuran Sampel Menurut Para Ahli. http://teorionlinejurnal.wordpress.com/2 012/08/20/menentukan-ukuran-sampelmenurut-para-ahli/

Kemenkes RI. 2014. Pusat Data dan Informasi Kementerian Kesehatan RI : Hipertensi. Jakarta.
Lastri. 2009. Efektifitas Mengkudu Terhadap Penurunan Tekanan Darah Pada Penderita Hipertensi. http://getskripsi.com/2009/10/21/efektifit as-mengkudu-terhadap-penurunantekanan-darah-pada-penderitahipertensi-di-desa-dagangan-kecamatandagangan-kabupaten-madiun

Muniroh L. 2014. Pengaruh pemberian jus buah belimbing dan mentimun terhadap penurunan tekanan darah sistolik dan diastolik penderita hipertensi, Jurnal Penelitian

Notoatmodjo. 2010. Metodologi Penelitian Kesehatan. Rineka Cipta. Jakarta

RSUD Padang Panjang, 2015, 2016.Medikal Record RSUD Padang Panjang.

Soedarya. 2009. Budidaya - Usaha Pengelolaan Agrobisnis Belimbing.CV Pustaka Grafika. Bandung

Sugiyono. 2010. Metode Penelitian Kuantitatif Kualitatif dan $R \& D$. Alfabeta. Bandung

Sulistiyono H. 2011. Pemberian jus belimbing demak (averroe carambola I) berpengaruh terhadap penurunan tekanan darah sistolik dan diastolik pada penderita hipertensi, Jurnal Penelitian.

Sulistiyono \& Isnawati. 2011.Pemberian Jus Belimbing Demak (Averrhoe carambola I) Berpengaruh Terhadap Penurunan Tekanan darah Sistolik dan Diastolik Pada Penderita Hipertensi.Jurnal Gizi Klinik Indonesia Vol. 7

Susilo Y \& Wulandari A. 2011. Cara Jitu Mengatasi Darah Tinggi (Hipertensi). Penerbit Andi. Yogyakarta 